\title{
Neonatal Resuscitation Preparedness Among Healthcare Provider: A Systematic Review
}

\author{
Ika Rizki Anggraini ${ }^{1}$, Kuswantoro Rusca Putra ${ }^{2}$, Setyoadi ${ }^{3}$ \\ ${ }^{1}$ Master Program of Nursing, Faculty of Medicine, Brawijaya University, Indonesia \\ ${ }^{2,3}$ Faculty of Medicine, Brawijaya University, Indonesia \\ Email: ika02anggraini@gmail.com
}

\begin{abstract}
Neonatal asphyxia is a form of gravity that occurs in neonates. It is a condition when the baby cannot breathe spontaneously and regularly after birth. The management of neonatal resuscitation is carried out by the health team. It is provided by nurses, midwives, and physicians. To identify the evidence of health team readiness in administering neonatal emergencies is useful to succeed neonatal resuscitation. The selection was conducted by following PRISMA flow diagram. It was also criticized by JBI tool. The search keywords were "Readiness Factor" and "Neonatal Resuscitation". The steps consisted of making questions, identifying, eligibility, article inclusion selection, screening, and appraisal. After 11 relevant articles were collected, they were analyzed in a systematic review. The finding shows that readiness in carrying out neonatal resuscitation requires preparation from both the health team that administers these actions. It consists of six dimensions. These dimensions are knowledge, clinical skills, self-efficacy, handling algorithms, facilities, and medicine. They are interrelated with one another towards a successful neonatal resuscitation.
\end{abstract}

Keyword: Readiness Factor, Neonatal Resuscitation.

\section{A. INTRODUCTION}

Newborn infant (neonates) is a 0-28-day-old infant born at 37-40 weeks gestational age and is 2500-4000 gram weight (Budiwardhana, 2011). Neonates are individuals who adjust themselves from intrauterine life to extra uterine life. Therefore, there are some newborns can normally adapt. There are several conditions of neonates that may fall within emergency conditions. Infant Mortality Rate (IMR) is the number of infant deaths (0-12 months) per 1.000 live births in one year (Gilang et al., 2010). Neonatal asphyxia has contributed significantly to morbidity and mortality. Asphyxia is a condition that is defined as the inability of the newborn to start and maintain adequate respiration after birth (Alemu et al., 2019). The risky factors of neonatal asphyxia are maternal, placental, fetal, and labor factors (Manuaba 2007.Pdf, n.d.). Asphyxia condition is a condition that is correlated to circulatory problems caused by various factors that will lead to permanent damage to the central nervous system or other vital organs that may fall on gravity conditions.

Neonatal resuscitation is an event with high complexity for the concerning and responsible team to administer appropriate resuscitation for the newborns (Gamboa et al., 2018). Neonatal resuscitation administrations involve a nurse, midwife, and doctor. The nurses and health workers should ideally have the readiness to handle such cases (Abrha et al., 2019). Handling during neonatal 
resuscitation requires speed and accuracy to take action. Thus, it requires necessary skills such as cognitive, psychomotor, and excellent communication to identify problems and analyze complex cases. Through this systematic review, the author expects to find out more about the contributive factors to the readiness of nurses in neonatal resuscitation treatment.

\section{B. METHOD}

This systematic review steps determined the research question in PICO method. The sample selection consists of nurses who handle neonatal resuscitation.The researchers collected by identifying, screening, selecting eligible articles, and determining the articles based on the inclusion criteria. They must follow PICO method and are written in English. The applied databases were Proquest, Pubmed, Ebscohost, and Science Direct.

The research question in this review section, "what factors influence readiness to administer neonatal resuscitation?. The process of literature search and selection are depicted in (figure 1). The searches were on four databases: Proquest, Pubmed, Ebscohost, and Science Direct by keyword "nursing readiness" and "neonatal resuscitation" from 2015-2019. They were taken through an integration which used the word "and".

\section{RESULT AND DISCUSSION}

There were 2,462 articles from Science Direct, 2,619 articles from Pubmed, 4,665 articles from Ebscohost, and 2,519 articles from Proquest. These results were combined by "and" and resulted in 242 items from Science Direct, 4 items from PubMed, 14 articles from Ebscohost, and 36 articles from Proquest. Based on the inclusion criteria, 11 final articles were obtained from all databases. The appraisal stage is to assess the existing 11 items. At this stage, the author summarized the article and evaluated it by using JBI tool on each item according to the method. The assessment results are shown in Figure 1. 


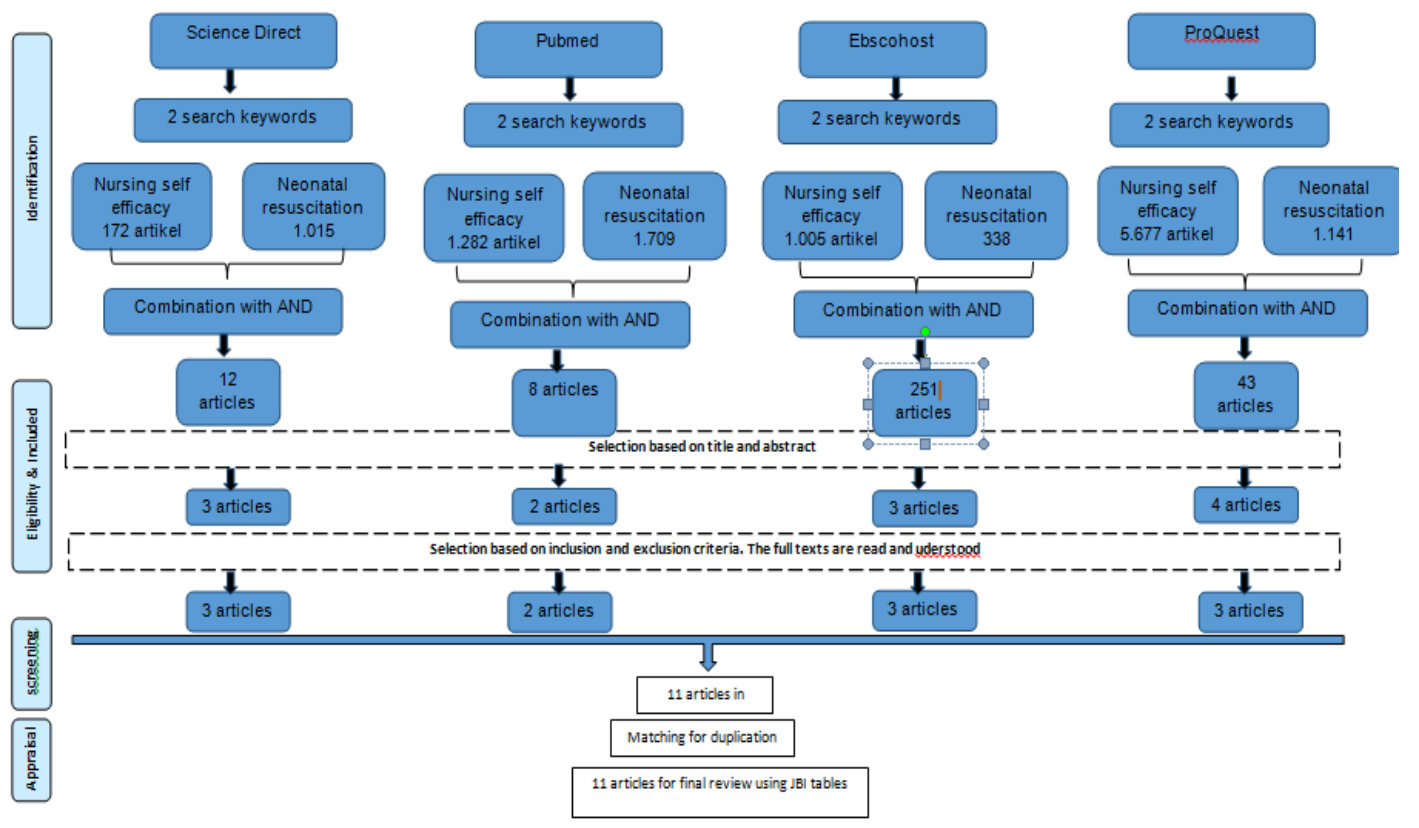

Figure 1. Framework Search Process of the Article Selection based on the Modified PRISMA

Table 1. Eligible Articles to be Reviewed

\begin{tabular}{|c|c|c|c|c|c|c|}
\hline No & $\begin{array}{c}\text { Author\&y } \\
\text { ear }\end{array}$ & Objectives & Methods & Sample & $\begin{array}{c}\text { Data } \\
\text { Analysis }\end{array}$ & $\begin{array}{c}\text { Major } \\
\text { Findings }\end{array}$ \\
\hline 1 & $\begin{array}{l}\text { (Trevisan } \\
\text { uto et al., } \\
2015 \text { ) }\end{array}$ & 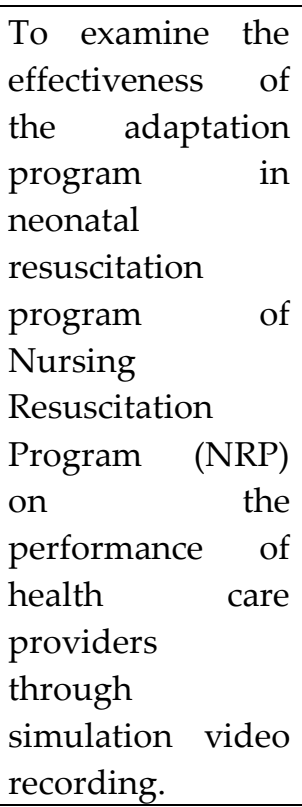 & $\begin{array}{l}\text { Analytical } \\
\text { observation } \\
\text { al }\end{array}$ & $\begin{array}{l}100 \\
\text { neonates } \\
\text { require } \\
\text { neonatal } \\
\text { resuscitatio } \\
\mathrm{n}, 77 \text { and } 32 \\
\text { using the } \\
\text { BVM }\end{array}$ & $\begin{array}{l}\text { fisheries and } \\
\text { Mann- } \\
\text { Whitney test. }\end{array}$ & $\begin{array}{l}\text { The results } \\
\text { showed that } \\
\text { an increase in } \\
\text { clinical } \\
\text { performance } \\
\text { after } \\
\text { simulation } \\
\text { with video } \\
\text { recording was } \\
\text { useful for an } \\
\text { objective } \\
\text { assessment of } \\
\text { the } \\
\text { performance } \\
\text { of the staff } \\
\text { during } \\
\text { resuscitation. }\end{array}$ \\
\hline 2 & $\begin{array}{l}\text { (Khalid et } \\
\text { al., 2015) }\end{array}$ & $\begin{array}{l}\text { To assess the } \\
\text { knowledge of } \\
\text { health workers } \\
\text { that midwives are } \\
\text { working in } \\
\text { primary health } \\
\text { care facilities for } \\
\text { the handling of } \\
\text { the early neonatal }\end{array}$ & $\begin{array}{l}\text { Cross- } \\
\text { sectional } \\
\text { study }\end{array}$ & $\begin{array}{l}103 \text { health } \\
\text { workers } \\
\text { and } 54 \text { is } 49 \\
\text { is } \\
\text { midwife. }\end{array}$ & $\begin{array}{l}\text { SPSS } 16 \text { to } \\
\text { analyze the } \\
\text { statistical } \\
\text { analysis. }\end{array}$ & $\begin{array}{l}\text { They are } \\
\text { needed for } \\
\text { training in } \\
\text { regular service } \\
\text { of health } \\
\text { workers and } \\
\text { midwives on } \\
\text { women's } \\
\text { health Basic }\end{array}$ \\
\hline
\end{tabular}




\begin{tabular}{|c|c|c|c|c|c|c|}
\hline & & resuscitation. & & & & $\begin{array}{l}\text { neonatal } \\
\text { resuscitation. }\end{array}$ \\
\hline 3 & \begin{tabular}{l}
\multicolumn{2}{l}{ Shikuku } \\
et al., \\
$2017)$
\end{tabular} & $\begin{array}{l}\text { This study aims } \\
\text { to examine the } \\
\text { quality of service } \\
\text { during neonatal } \\
\text { Resuscitation }\end{array}$ & $\begin{array}{l}\text { Analytical } \\
\text { observation } \\
\text { al }\end{array}$ & $\begin{array}{l}8 \text { newborns } \\
\text { with } \\
\text { neonatal } \\
\text { resuscitatio } \\
\text { n. and } 28 \\
\text { health } \\
\text { workers }\end{array}$ & $\begin{array}{l}\text { SPSS was } \\
\text { used to } \\
\text { analyze the } \\
\text { statistical } \\
\text { analysis }\end{array}$ & $\begin{array}{l}\text { The critical } \\
\text { steps in the } \\
\text { treatment of } \\
\text { neonatal } \\
\text { resuscitation } \\
\text { require a } \\
\text { period that } \\
\text { needs to be } \\
\text { taken into } \\
\text { account to } \\
\text { improve the } \\
\text { quality of } \\
\text { work and } \\
\text { ensure that } \\
\text { safe to do. }\end{array}$ \\
\hline 4 & $\begin{array}{l}\text { (Bintabara } \\
\text { et al., } \\
2019 \text { ) }\end{array}$ & $\begin{array}{l}\text { To assess the } \\
\text { availability and } \\
\text { readiness of } \\
\text { health facilities in } \\
\text { essential services } \\
\text { and emergency } \\
\text { obstetric and } \\
\text { newborn care and } \\
\text { related factors. }\end{array}$ & $\begin{array}{l}\text { Cross- } \\
\text { sectional } \\
\text { study }\end{array}$ & $\begin{array}{l}\text { Used a } \\
\text { nationally } \\
\text { representati } \\
\text { ve sample } \\
\text { of Tanzania } \\
\text { as an } \\
\text { example of } \\
\text { low- } \\
\text { resource } \\
\text { settings } \\
\text { with a high } \\
\text { burden of } \\
\text { maternal } \\
\text { and } \\
\text { newborn. }\end{array}$ & $\begin{array}{l}\text { Using seven } \\
\text { sizes based } \\
\text { on the } \\
\text { provision of } \\
\text { antibiotics. }\end{array}$ & $\begin{array}{l}\text { Readiness is a } \\
\text { variable that is } \\
\text { measured by } \\
\text { the availability } \\
\text { of supporting } \\
\text { items that are } \\
\text { categorized } \\
\text { into three } \\
\text { domains: staff } \\
\text { training, } \\
\text { diagnostic } \\
\text { equipment, } \\
\text { and essential } \\
\text { drugs. }\end{array}$ \\
\hline 5 & $\begin{array}{l}\text { (Cordero, } \\
2013)\end{array}$ & $\begin{array}{l}\text { To evaluate the } \\
\text { procedural skills } \\
\text { and team } \\
\text { performance of } \\
\text { occupants uses } \\
\text { pediatrics during } \\
\text { neonatal } \\
\text { resuscitation. }\end{array}$ & $\begin{array}{l}\text { Analytical } \\
\text { observation } \\
\text { al }\end{array}$ & $\begin{array}{l}\text { Twenty-six } \\
\text { respondent } \\
\mathrm{s}\end{array}$ & $\begin{array}{l}\text { Wilcoxon } \\
\text { Test and } \\
\text { McNemar x2 } \\
\text { Test }\end{array}$ & $\begin{array}{l}\text { Twenty-six } \\
\text { residents (11 } \\
\text { teams) } \\
\text { completed two } \\
\text { sessions in } \\
\text { pairs. detected } \\
\text { bysimulation } \\
\text { training; can } \\
\text { increase } \\
\text { respondents } \\
\text { report } \\
\text { increased } \\
\text { confidence } \\
\text { after } \\
\text { simulation the } \\
\text { with } \\
\text { mannequin. a }\end{array}$ \\
\hline 6 & $\begin{array}{l}\text { (Healthstr } \\
\text { eam et al., }\end{array}$ & $\begin{array}{l}\text { To determine } \\
\text { whether }\end{array}$ & $\begin{array}{l}\text { Cross- } \\
\text { sectional }\end{array}$ & $\begin{array}{l}3,804 \text { health } \\
\text { care }\end{array}$ & $\begin{array}{l}\text { SPSS version } \\
21 .\end{array}$ & $\begin{array}{l}\text { Training based } \\
\text { neonatal }\end{array}$ \\
\hline
\end{tabular}




\begin{tabular}{|c|c|c|c|c|c|c|}
\hline & 2015) & $\begin{array}{l}\text { professional } \\
\text { knowledge about } \\
\text { resuscitation fatal } \\
\text { health and the } \\
\text { factors that } \\
\text { influence it. }\end{array}$ & study & providers & & $\begin{array}{l}\text { resuscitation } \\
\text { should be } \\
\text { conducted } \\
\text { with } \\
\text { simulation } \\
\text { methods to } \\
\text { provide } \\
\text { knowledge } \\
\text { and } \\
\text { preparation } \\
\text { during the } \\
\text { learning } \\
\text { process }\end{array}$ \\
\hline 7 & $\begin{array}{l}\text { (Jukkala \& } \\
\text { Henly, } \\
\text { 2007) }\end{array}$ & $\begin{array}{l}\text { To describe } \\
\text { thedevelopment } \\
\text { instruments } \\
\text { among } \\
\text { knowledge of } \\
\text { neonatal } \\
\text { resuscitation, } \\
\text { frequency } \\
\text { performance with } \\
\text { neonatal } \\
\text { resuscitation } \\
\text { skills, and self- } \\
\text { reported comfort } \\
\text { level to perform } \\
\text { neonatal } \\
\text { resuscitation. }\end{array}$ & $\begin{array}{l}\text { Descriptive, } \\
\text { correlationa } \\
1\end{array}$ & $\begin{array}{l}37 \text { to } 860 \\
\text { hospitals } \\
\text { with } 1,257 \\
\text { births, } \\
\text { while the } \\
\text { other has } \\
3,693 \\
\text { births. }\end{array}$ & $\begin{array}{l}\text { Pearson } \\
\text { correlation } \\
\text { and T-test. }\end{array}$ & $\begin{array}{l}\text { Knowledge on } \\
\text { neonatal } \\
\text { resuscitation, } \\
\text { performance } \\
\text { skills that } \\
\text { often, and } \\
\text { comfort level } \\
\text { with the } \\
\text { performance } \\
\text { skills are the } \\
\text { dimensions of } \\
\text { quality } \\
\text { implementatio } \\
n \text { of neonatal } \\
\text { resuscitation. }\end{array}$ \\
\hline 8 & $\begin{array}{l}\text { (Maya- } \\
\text { Enero et } \\
\text { al., 2018) }\end{array}$ & $\begin{array}{l}\text { To evaluate the } \\
\text { adherence to } \\
\text { guidelines of the } \\
\text { neonatal } \\
\text { resuscitation team } \\
\text { after birth in } \\
\text { preterm infants. }\end{array}$ & $\begin{array}{l}\text { Analytical } \\
\text { observation } \\
\text { al }\end{array}$ & $\begin{array}{l}162 \text { infants } \\
<32 \text { weeks } \\
\text { as the } \\
\text { respondent } \\
\text { s at } \\
\text { designated } \\
\text { hospitals. }\end{array}$ & $\begin{array}{l}\text { Chi-square } \\
\text { test and } \\
\text { Fisher's exact } \\
\text { test }\end{array}$ & $\begin{array}{l}\text { Resuscitation } \\
\text { led by } \\
\text { pediatricians } \\
\text { and } \\
\text { neonatologists } \\
\text { with a guided } \\
\text { algorithm and } \\
\text { intubation } \\
\text { training may } \\
\text { improve the } \\
\text { outcomes of } \\
\text { neonatal } \\
\text { resuscitation. }\end{array}$ \\
\hline 9 & $\begin{array}{l}\text { (Article et } \\
\text { al., 2019) }\end{array}$ & $\begin{array}{l}\text { To analyze the } \\
\text { knowledge of the } \\
\text { doctors who deal } \\
\text { with child } \\
\text { patients of } \\
\text { neonatal } \\
\text { resuscitation. }\end{array}$ & $\begin{array}{l}\text { Cross- } \\
\text { sectional } \\
\text { study }\end{array}$ & $\begin{array}{l}\text { A total of } \\
137 \text { doctors }\end{array}$ & $\begin{array}{l}\text { Data were } \\
\text { analyzed } \\
\text { using SPSS } \\
\text { version } 20 .\end{array}$ & $\begin{array}{l}\text { Needed } \\
\text { training } \\
\text { neonatal } \\
\text { resuscitation is } \\
\text { often done to } \\
\text { improve } \\
\text { neonatal } \\
\text { outcomes. }\end{array}$ \\
\hline
\end{tabular}




\begin{tabular}{|c|c|c|c|c|c|c|}
\hline 10 & $\begin{array}{l}\text { (Olson et } \\
\text { al., 2015) }\end{array}$ & $\begin{array}{l}\text { To understand } \\
\text { the extent of } \\
\text { knowledge and } \\
\text { self-efficacy in } \\
\text { their } \\
\begin{array}{l}\text { contributions to } \\
\text { resuscitation } \\
\text { efforts }\end{array}\end{array}$ & $\begin{array}{l}\text { Retrospecti } \\
\text { ve cohort }\end{array}$ & $\begin{array}{l}348 \\
\text { midwives } \\
\text { who have } \\
\text { to handle } \\
3116 \text { birth }\end{array}$ & Path analysis & $\begin{array}{l}\text { Training has } \\
\text { an impact on } \\
\text { resuscitation } \\
\text { efforts } \\
\text { indirectly } \\
\text { through } \\
\text { relationships } \\
\text { with self- } \\
\text { efficacy and } \\
\text { knowledge. }\end{array}$ \\
\hline 11 & $\begin{array}{l}\text { (Heathcot } \\
\text { e et al., } \\
2018 \text { ) }\end{array}$ & $\begin{array}{l}\text { To describe } \\
\text { neonatal survival } \\
\text { time of the events } \\
\text { observed } \\
\text { resuscitation of } \\
\text { newborns who } \\
\text { requirehandling } \\
\text { of resuscitation. }\end{array}$ & $\begin{array}{l}\text { Retrospecti } \\
\text { ve. }\end{array}$ & $\begin{array}{l}6000 \text { births } \\
\text { per year }\end{array}$ & $\begin{array}{l}\text { By using the } \\
\text { documentati } \\
\text { on of events } \\
\text { and the } \\
\text { results of } \\
\text { neonatal } \\
\text { resuscitation. }\end{array}$ & $\begin{array}{l}\text { Time-critical } \\
\text { resuscitation } \\
\text { events and } \\
\text { often } \\
\text { overlooked in } \\
\text { the } \\
\text { documentatio } \\
n \text { that could } \\
\text { provide a basis } \\
\text { for quality } \\
\text { improvement } \\
\text { in neonatal } \\
\text { resuscitation. }\end{array}$ \\
\hline
\end{tabular}

According to the analysis of several articles, several components should have been owned by nurses in neonatal resuscitation readiness. They played essential roles in success. Those components include the knowledge, training simulations, documentation of activities, duration, algorithms, resuscitation equipment, drugs, and self-efficacy. Knowledge in performing neonatal resuscitation becomes an integral part of the health care system that may impact on successful handling (Khalid et al., 2015). Another study conducted by Jukkala \& Henly (2007) describes the relationship test among knowledge of neonatal resuscitation, frequency of performance with neonatal resuscitation skills, and comfort level self-reported by conducting tasks that associated with neonatal resuscitation. The study was conducted at 37 to 860 hospitals with 1,257 births while the other had 3,693 births. The study found that knowledge of neonatal resuscitations, performance skills, and comfort levels with the performance of skills was included in the dimension of the quality of neonatal resuscitation. Knowledge of the newborn resuscitation could prevent the consequences of asphyxia resuscitation procedures in newborns. It played important roles in early diagnosis, proper management, and reduce the number of complications in newborns with life-threatening conditions (Abrha et al., 2019) .

Clinical skills have significant contributions to the treatment of neonatal resuscitation. Based on the strategy, to decrease mortality rates in neonates could be conducted by providing training for people who were still studying or were already working. According to several articles, to improve education about neonatal 
resuscitation could be done by consistently teaching the skills that could be applied for clinical practice (Trevisanuto et al., 2015). Research conducted Shikuku et al (2017). Examined the quality of service during neonatal resuscitation at 8 newborns and 28 health workers. They found that the critical steps in the treatment of neonatal resuscitation required a period that should be taken into account to improve the quality of work and ensure its safety.

The training method with the simulation of video recording has been used to evaluate the performance of neonatal resuscitation of health care providers in high-resource settings (Trevisanuto et al., 2015). A training method using the simulation could be useful to facilitate learning by providing knowledge in a controlled and secure environment that could make the nurses exposed to specific events and could increase self-confidence (self-efficacy). After completion of this program, it is expected to show readiness for neonatal resuscitation that has become a gap over the years related to the availability of citizens to perform neonatal resuscitation (Cordero, 2013). Research conducted by Olson et al (2015) aimed to understand the extent of knowledge and self-efficacy that contributed to resuscitation efforts of 348 midwives who had to handle 3,116 births. It was conducted by a retrospective cohort design. The results showed indirect influences on resuscitation efforts through its relationship with self-efficacy and knowledge.

Algorithm guidance on neonatal resuscitation is frequently conducted in a hospital that has interventions during the transition after birth and viability. Their prognoses are highly dependent on the care they receive in the delivery room. Most premature babies start breathing after birth but they often have weak and poor respiratory boosts. Guidelines/algorithms recommend tactile stimulation (warm, dry, and rub his back or legs) to stimulate breathing. They are the standard guidelines and could optimize resuscitation. Research conducted by (Maya-Enero et al., 2018). about the resuscitation team, evaluated the adherence of the guidelines for neonatal resuscitation after birth in preterm infants. It was done by analytical observational study design. The results showed that resuscitation led by a pediatrician and neonatologist with intubation training guides accompanied the algorithm could improve the outcomes of neonatal resuscitation.

The Standard of time is an integral part of the implementation of neonatal resuscitation. It is the determination of time duration during the action. The timing should be considered and examined thoroughly to achieve success and improve survivability. To improve the standards concerning newborn resuscitation, it is important to ensure the time is right for action. The time should be described in real life when certain essential events resuscitation achieved in newborn resuscitation (Heathcote et al., 2018). Adequate facilities are needed in the handling of neonatal resuscitation. Evidence from around the world also showed that the risk of death increased by $16 \%$ for every 30 seconds of delay. Therefore, it is clear that the first minute after birth is crucial to decrease neonatal mortality (Shikuku et al., 2017). Evidence shows that successful neonatal resuscitation by trained health care providers, in providing proper and adequate resuscitation, has the potential to 
prevent mortality. The need for urgent referral to specialist facilities asphyxia cases is higher. It can also help to prevent some of these complications if early anticipations are carried out (Shikuku et al., 2018).

The findings from this study will provide essential guidelines concerning essential factors that need to be addressed to strengthen services for policymakers, administrators, and researchers in each relevant agency (Bintabara et al., 2019). Neonatal asphyxia has been identified as a significant cause ofworldwide neonatal mortality. Globally, about $25 \%$ of all infant mortalities are caused by neonatal asphyxia. Neonatal asphyxia is defined by the World Health Organization as a failure to initiate and sustain breathing at birth (Alhassan et al., 2019). Neonatal resuscitation is an action taken by the complexity and high stress for the team that is responsible for neonatal care. Success in conducting neonatal resuscitation skills is correlated to the survival of newborns who cannot breathe spontaneously

American Heart Association (AHA) has a program that adopts simulation techniques. It designs the educational program for the acquisition and maintenance of skills necessary for adequate neonatal resuscitation (Wyckoff et al., 2015). Management guidelines for neonatal resuscitation or algorithm are also outlined in the guidelines covering the handling of the airway, oxygenation, or medication. Other studies have shown that there is value in use that may affect the development of competence in provisioning, such as the type and quality of video recordings; the selection of video segments which allows highlighting the learning objectives; the number of times a video is reviewed; time, space, and the duration of the briefing; and the expertise and knowledge of instructors who conduct a training (Gamboa et al., 2018).

\section{CONCLUSION}

According to the five components that affect the readiness of neonatal resuscitation, it includes the dimensions of knowledge, clinical skills, self-efficacy, treatment algorithms, facilities, and medicines. These dimensions are interrelated one to another so that successful neonatal resuscitation could be the basis for the institution of policy-making related to neonatal resuscitation in the hospital.

\section{REFERENCES}

1. Abrha, M. W., Asresu, T. T., Araya, A. A., \& Weldearegay, H. G. (2019). Healthcare Professionals' Knowledge of Neonatal Resuscitation in Ethiopia: Analysis from 2016 National Emergency Obstetric and Newborn Care Survey. International Journal of Pediatrics, 2019, 1-7. https://doi.org/10.1155/2019/8571351

2. Alemu, A., Melaku, G., Abera, G. B., \& Damte, A. (2019). <p >Prevalence and associated factors of perinatal asphyxia among newborns in Dilla University referral hospital, Southern Ethiopia- 2017</p $>$. Pediatric Health, Medicine and Therapeutics, Volume 10, 69-74. https://doi.org/10.2147/phmt.s196265 
3. Alhassan, A., Fuseini, A.-G., Osman, W., \& Basour Adam, A. (2019). Knowledge and Experience of Neonatal Resuscitation among Midwives in Tamale. Nursing Research and Practice, 2019, 1-8. https://doi.org/10.1155/2019/3652608

4. Article, O., Muneer, A., Bari, A., Haider, A., \& Ali, A. S. (2019). Knowledge of clinicians / pediatricians about neonatal resuscitation in a tertiary care hospital. 35(3).

5. Bintabara, D., Ernest, A., \& Mpondo, B. (2019). Health facility service availability and readiness to provide basic emergency obstetric and newborn care in a lowresource setting: Evidence from a Tanzania National Survey. BMJ Open, 9(2), 110. https://doi.org/10.1136/bmjopen-2017-020608

6. Budiwardhana, N. (2011). Pediatri Gawat Darurat.

7. Cordero, L. (2013). Pediatrics Residents' Preparedness for Neonatal Resuscitation Assessed Using High-Fidelity Simulation. 17, 19-24.

8. Gamboa, O. A., Agudelo, S. I., Maldonado, M. J., Leguizamón, D. C., \& Cala, S. M. (2018). Evaluation of two strategies for debriefing simulation in the development of skills for neonatal resuscitation: A randomized clinical trial NCT03606278 NCT. BMC Research Notes, 11(1), 1-5. https://doi.org/10.1186/s13104-018-3831-6

9. Gilang, Notoatmodjo, H., \& Rakhmawatie, M. D. (2010). Faktor- Faktor Yang Berhubungan Dengan Kejadian Asfiksia Neonatorum ( Studi Di RSUD Tugurejo Semarang ). Jurnal Kedokteran Muhammadiyah, 2, 11-19.

10. Healthstream, Perlman, J. M., Kattwinkel, J., Wyllie, J., Guinsburg, R., Velaphi, S., Boyle, D., Branco de Armeida, M. F., Davis, P., Escobedo, M. B., Goldsmith, J., Halamek, L. P., Lily, H., McGowan, J. E., Mcmillan, D., Niermeyer, S., O’Donnell, C., Rabi, Y., Simon, W. M., ... Lawn, J. E. (2015). Resusitasi Neonatus. Pediatrics, 136(1), 12. https://doi.org/10.1542/peds.2015-3373F

11. Heathcote, A. C., Jones, J., Clarke, P., Clarke, P., \& Heathcote, A. C. (2018). Timing and documentation of key events in neonatal resuscitation. 1053-1056.

12. Jukkala, A. M., \& Henly, S. J. (2007). Readiness for neonatal resuscitation: Measuring knowledge, experience, and comfort level. Applied Nursing Research, 20(2), 78-85. https://doi.org/10.1016/j.apnr.2006.01.006

13. Khalid, N., Ahmad, M., Tahir, A., Mahmood, H., Saleem, S., \& Saleem, S. (2015). Basic neonatal resuscitation, knowledge assessment at primary health care centers of district sheikhupura in Pakistan - a cross-sectional study. Journal of the Pakistan Medical Association, 65(9), 990-994.

14. Manuaba 2007.Pengantar Kuliah Obstetri. Jakarta : EGC.

15. Maya-Enero, S., Botet-Mussons, F., Figueras-Aloy, J., Izquierdo-Renau, M., Thió, M., \& Iriondo-Sanz, M. (2018). Adherence to the neonatal resuscitation algorithm for preterm infants in a tertiary hospital in Spain. BMC Pediatrics, 18(1), 1-11. https://doi.org/10.1186/s12887-018-1288-3

16. Olson, K. R., Caldwell, A., Sihombing, M., Guarino, A. J., Nelson, B. D., \& Petersen, R. (2015). Assessing self-efficacy of frontline providers to perform newborn resuscitation in a low-resource setting. Resuscitation, 89, 58-63. https://doi.org/10 .1016/j.resuscitation. 015.01.008 
17. Shikuku, D. N., Milimo, B., Ayebare, E., Gisore, P., \& Nalwadda, G. (2017). Quality of care during neonatal resuscitation in kakamega county general hospital, Kenya: A direct observation study. BioMed Research International, 2017. https://doi.org/10.1155/2017/2152487

18. Shikuku, D. N., Milimo, B., Ayebare, E., Gisore, P., \& Nalwadda, G. (2018). Practice and outcomes of neonatal resuscitation for newborns with birth asphyxia at Kakamega County General Hospital, Kenya: A direct observation study. BMC Pediatrics, 18(1), 1-12. https://doi.org/10.1186/s12887-018-1127-6

19. Trevisanuto, D., Bertuola, F., Lanzoni, P., Cavallin, F., Matediana, E., Manzungu, O. W., Gomez, E., Da Dalt, L., \& Putoto, G. (2015). Effect of a neonatal resuscitation course on healthcare providers' performances assessed by video recording in a low-resource setting. PLoS ONE, 10(12), 1-13. https://doi.org/10.1371/journal.pone.0144443

20. Wyckoff, M. H., Aziz, K., Escobedo, M. B., Kapadia, V. S., Kattwinkel, J., Perlman, J. M., Simon, W. M., Weiner, G. M., \& Zaichkin, J. G. (2015). Part 13: Neonatal resuscitation 2015 American Heart Association guidelines update for cardiopulmonary resuscitation and emergency cardiovascular care (Reprint). Pediatrics, 136, S196-S218. https://doi.org/10.1542/peds.2015-3373G 